\title{
DIVERSITY AND ABUNDANCE OF GASTROPODS IN THE INTERTIDAL ZONE OF WATUKARUNG, INDONESIA
}

\author{
Dwi Eny Djoko Setyono ${ }^{1,2^{*}}$, Hollanda Arief Kusuma ${ }^{3,4}$, Nandike Ayudiah Poeteri' ${ }^{5}$, Dietriech \\ Geoffrey Bengen ${ }^{5}$ and Ferry Kurniawan ${ }^{5,6}$ \\ ${ }^{1}$ Research Center for Oceanography, Indonesian Institute of Sciences (LIPI). Jakarta, Indonesia. \\ ${ }^{2}$ Now at Research Unit for Natural Product Technology, Indonesian Institute of Sciences (LIPI). Yogyakarta, \\ Indonesia. \\ ${ }^{3}$ Center for Marine and Coastal Environment Mapping, Geospatial Information Agency (BIG). Cibinong, Indonesia. \\ ${ }^{4}$ Now at Faculty of Engineering, Universitas Maritim Raja Ali Haji. Tanjung Pinang, Indonesia. \\ ${ }^{5}$ Faculty of Fisheries and Marine Sciences, Bogor Agricultural University (IPB). Bogor, Indonesia. \\ ${ }^{6}$ Center for Coastal and Marine Resources Studies, Bogor Agricultural University (IPB). Bogor, Indonesia. \\ *Correspondence author: <setdwi@yahoo.co.nz>
}

Received: October 2018 Accepted: June 2019

\begin{abstract}
We present the density, diversity, and environmental conditions of gastropods in the Watukarung intertidal zone - a coastal region of Pacitan Regency, Indonesia, adjoining the Indian Ocean. Gastropods play an important role in coastal ecosystems. In Watukarung, the local people collect marine organisms, including gastropods during low tide to supplement their income. Baseline information on the presence and abundance of gastropods in Watukarung are not available. Our survey collected 173 individuals of gastropod in the intertidal area of Watukarung that represent 8 families, 9 genera, and 13 species. Gastropod diversity index $\left(\mathrm{H}^{\prime}\right)$ in the three beaches (Ngalorombo, Pasir Putih, and Kasap) show varying values from the categories of low and medium species diversity. Although the data suggest that there should be a dominant species in the ecosystem $(\mathrm{E}<0.5)$, there are no strong dominance species in the community $(\mathrm{C}<0.5)$. Watukarung coastal waters are still in good condition for marine organisms with salinity $>31 \%, \mathrm{DO}>8.1 \mathrm{mg} / \mathrm{L}$, and $\mathrm{pH}>8$. The substrate is dominated by coarse sand. The total organic matter is relatively low $(<2.6 \%)$ due to characteristics of the substrate that is dominated by a rocky and sandy substrate. Based on the results, we suggest that Kasap beach can be established as a core zone considering its high diversity and density of gastropods as well as being distant from any residential area, whereas Ngalorombo and Pasir Putih beaches are suitable as usage zones for surfing tourism. We highlight the need for the local community, government, and private sector need to work together to encourage sustainably tourism while reducing environmental impacts in Watukarung.
\end{abstract}

Keywords: Gastropod, intertidal zone, Watukarung, diversity index, Indonesia.

\section{INTRODUCTION}

Gastropods comprise the largest number of species amongst the mollusks in the world with a current estimate of some 140,000 species worldwide (Reid, 1985; De Kock et al., 1989; Davis et al., 2015). Gastropods play an important role in an ecosystem; they are prey for other species, encourage decomposition of dead aquatic plants, and recycle nutrients (Bloch, 2012). Gastropods also control the growth of macroalgae and epiphytes (Picardal and Dolorosa, 2014). Gastropods are known to have important values for local people. The meat is 
used as a food resource with high protein, and the shell is used for making souvenirs (Poutiers, 1998; Bloch, 2012).

Gastropods can adapt to various types of marine, freshwater, and terrestrial habitats, including the intertidal zone at the intersection of terrestrial and marine realms (Mouritsen and Poulin, 2002). The intertidal zone is always subject to the tidal regime, which is accompanied by changes in temperature and turbidity (Smale et al., 2012; Davis et al., 2015). Some intertidal zones have flat reef platforms comprising of limestone and sand. Gastropods that live in this zone have a capability to adapt to extreme environmental conditions by withstanding thermal stress from exposure to the sun, tolerating wave action, and surviving changes in osmotic pressure due to rainwater at low tide (Mouritsen and Poulin, 2002). The intertidal area is also a region that is directly affected by human activities as it is within easy reach by the local human community who collect marine organisms during low tide as a source of food and revenue (Yulianda et al., 2013).

The village of Watukarung is located on the southern coast of Java overlooking the Indian Ocean in Indonesia. The village encompasses nine nearby coastal areas, where each coastal area is about 1-3 kilometers away and has become a source of revenue for the local community from tourism and fisheries besides farming on land. Large waves off the Watukarung village has attracted tourism as a destination for surfing. The majority of people in Watukarung Village are fishers who use boats and sell their catches at a nearby market. During low tide, marine algae and animals such as gastropods are collected for food as well as to be sold as souvenirs - adding their income from fisheries. However, basic information on the presence and abundance of gastropods in Watukarung lack, while there are concerns that the gastropods could be over exploited because they provide a significant source of seafood. Therefore, this study aims to determine the gastropod diversity, habitat preferences, and environmental conditions in the Watukarung intertidal zone. The information is needed to be a baseline study that can serve as a future indicator for sustainable management of fisheries resources and further ecological studies.

\section{MATERIALS AND METHODS}

\section{Study Site}

We conducted the study in the intertidal zone of Watukarung village in Pacitan Regency, East Java Province, on the south coast of Java Island

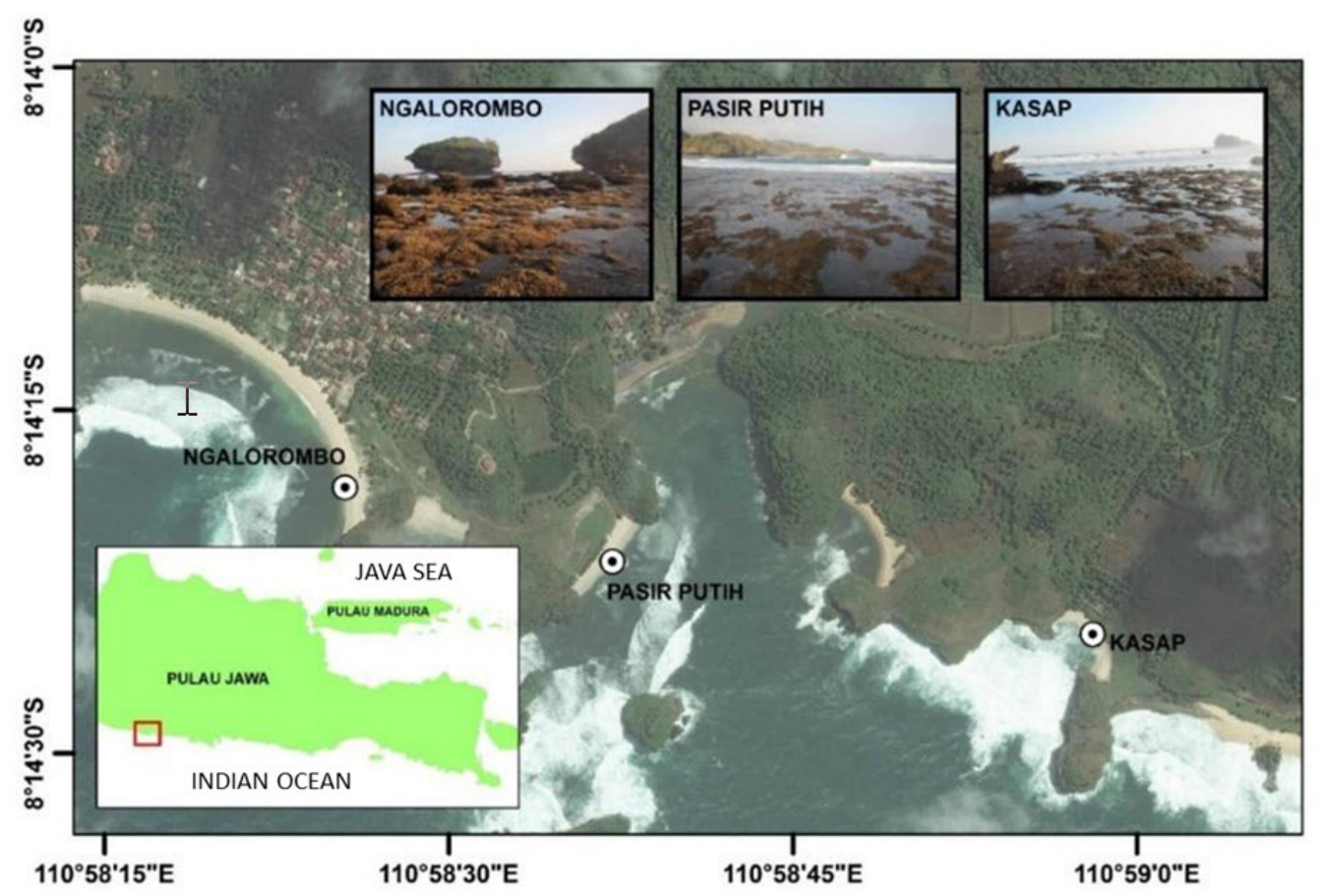

Figure 1. Study sites in Watukarung namely Ngalorombo, Pasir Putih and Kasap beaches. 

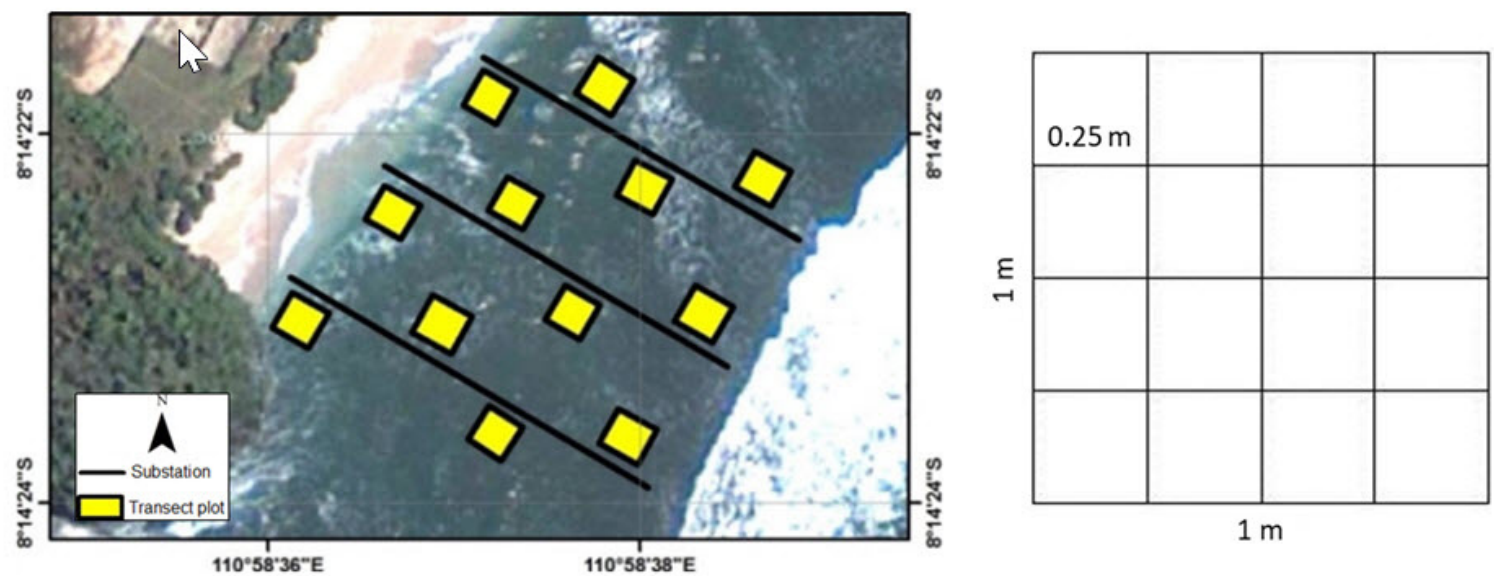

Figure 2. (Left) Transect lines and quadrats placement at each site. (Right) Transect quadrat for gastropod observation.

Indonesia. The distance between Watukarung from the nearest Pacitan City is approximately 40 $\mathrm{km}$. The village has nine beaches, of which three are often visited by villagers during low tide to collect sea food. These three beaches are chosen as sampling locations, which are Ngalorombo, Pasir Putih, and Kasap. The physical condition of the three beaches is similar, i.e., a beach with a rocky platform and coarse sand (Figure 1).

The three beaches differ in their exposure to strong waves and visitors. Ngalorombo beach has a small island in front of the beach that becomes a barrier for incoming strong large waves into the coastal area, therefore that the incoming water does not destroy the structure of the rocky coastal areas covered with coral reefs. In contrast, the rocky and sandy beaches at Pasir Putih and Kasap are facing directly the Indian Ocean from which strong waves can enter the coast up to 5 meters horizontally during high tide. During low tide, tide pools can be seen at Pasir Putih and Kasap. According to Nybakken (1988), the distinctive features of the rocky coast is tide pools of any size, depth, and location. Pasir Putih beach is the second beach frequently visited by villagers looking for gastropods and seaweed. Kasap beach is rarely visited because it is further from the village compared to Ngalorombo and Pasir Putih beaches.

\section{Samples Collection and Processing}

Samples were collected in Ngalorombo, Pasir Putih, and Kasap beaches on August 2429, 2014, using a combination of transects lines and quadrats, where three $40 \mathrm{~m}$-long transect lines were laid perpendicular to the coastline in each station. Transect quadrats were placed in every transect line, set zigzagged along the transect lines with a distance of $10 \mathrm{~m}$ between each transect quadrat (Figure 2-left). Each of the quadrats is $1 \times 1 \mathrm{~m}^{2}$ in dimension with 16 inner quadrats of $0.25 \times 0.25 \mathrm{~m}^{2}$ (Figure 2-right). We handpicked gastropods found on the surface of the substrate or attached to a rock or stone within in the $1 \times 1 \mathrm{~m}^{2}$ quadrats, where a representative species of gastropods put into plastic bags and transferred to the laboratory. We identified the species using following Abbott (1969) and check the validity of the species name using the World Register of Marine Species (WoRMS).

Samples of substrate were taken from the surface on several transects that represent the observation area, and each sample was placed in a plastic bag for grain size and total organic matter (TOM) analyses at Aquaculture Laboratory. GRADISTAT program was used to classify the substrate fraction (Blott and Pye, 2001). TOM - the total of dissolved organic matter, suspended, and colloids in water properties, has an important role in water productivity. Water quality parameters (temperature, salinity, $\mathrm{pH}$, and DO) were also observed in situ using Dissolved Oxygen Meter (DO-5510 CT Lutron, Taiwan) for measuring DO, pH Meter (HI 8915 ATC, Italy) for measuring $\mathrm{pH}$ and temperature, and a refractometer for measuring salinity. These parameters were observed three times in each station. 


\section{Data Analysis}

We calculated density, Shannon-Wiener diversity index, evenness index, and Simpson dominance index at each station following Brower and Zar (1990) and Odum (1993). Density (S) is defined as the number of organisms per unit area. The Shannon Wiener index $\left(\mathrm{H}^{\prime}\right)$ follows the formula:

$$
H^{\prime}=-\sum[p i \cdot \ln (p i)] \quad \text { Eq. } 1
$$

The relationship between the Shannon-Wiener diversity index $\left(\mathrm{H}^{\prime}\right)$ and gastropods community stability is expressed in three ranges of stability (e.g. Silulu et al., 2013): (i) low species diversity $\left(0<\mathrm{H}^{\prime} \leq 1\right)$; (ii) medium species diversity $(1<$ $\left.\mathrm{H}^{\prime} \leq 3\right)$, and (iii) high species diversity $\left(\mathrm{H}^{\prime}>3\right)$. Evenness index (E) is calculated based on the equation:

$$
E^{\prime}=\frac{H^{\prime}}{\log 2 S}
$$

According to Brower and Zar (1990), the evenness index value ranges from 0 to 1 . An evenness index towards a value of 0 infers a trend of dominant species in the ecosystem, whereas an evenness index value close to 1 implies a tendency of relatively good condition in the ecosystem where the numbers of individuals of each species are relatively equal. The Simpson dominance index (D) is calculated based on the formula:

$$
C=\sum[p i]^{2}
$$

According to Odum (1993), the dominance index value ranges from 0 (no dominant species) to 1 (a dominant species).

\section{RESULTS}

\section{Diversity and Density of Gastropods}

We collected 173 gastropods from the intertidal area of Watukarung that comprise of 8 families, 10 genera, and 13 species. Gastropod density in all the three sites is $4 \pm 0.57$ individuals per $10 \mathrm{~m}^{2}$, of which the density is $2 \pm 0.82$ individuals per $10 \mathrm{~m}^{2}$ in Ngalorombo beach, $4 \pm$ 0.38 individuals per $10 \mathrm{~m}^{2}$ in Pasir Putih beach, and $6 \pm 1.45$ individuals per $10 \mathrm{~m}^{2}$ in Kasap beach. The eight families consist of Cypraeidae (5 species), Muricidae (2 species), and Turbinidae, Strombidae, Cymatiidae, Bursidae, Fasciolariidae, and Conidae (1 species each)

\begin{tabular}{|c|c|c|c|}
\hline \multirow{2}{*}{ Species } & \multicolumn{3}{|c|}{ Site } \\
\hline & Ngalorombo & Pasir Putih & Kasap \\
\hline \multicolumn{4}{|l|}{ MURICIDAE } \\
\hline Tenguella granulata (Duclos, 1832) & $1 \pm 0.83(\mathrm{n}=1)$ & $8 \pm 6.75(n=10)$ & $1 \pm 1.44(\mathrm{n}=1)$ \\
\hline Drupa morum (Röding, 1798) & - & - & $7 \pm 5.64(\mathrm{n}=8)$ \\
\hline \multicolumn{4}{|l|}{ CYPRAEIDAE } \\
\hline Ovatipsa chinensis (Gmelin, 1791) & - & $8 \pm 9.01(n=9)$ & - \\
\hline Monetaria caputserpentis (Linnaeus, 1758) & $5 \pm 4.67(n=3)$ & $3 \pm 2.17(n=4)$ & $4 \pm 3.82(n=5)$ \\
\hline Monetaria annulus (Linnaeus, 1758) & - & - & $24 \pm 6.56(n=29)$ \\
\hline Monetaria moneta (Linnaeus, 1758) & $3 \pm 2.17(n=4)$ & $3 \pm 2.57(\mathrm{n}=3)$ & $27 \pm 3.57(\mathrm{n}=32)$ \\
\hline Mauritia arabica (Linnaeus, 1758) & - & - & $3 \pm 4.33(\mathrm{n}=3)$ \\
\hline \multicolumn{4}{|l|}{ FASCIOLARIIDAE } \\
\hline Filifusus filamentosus (Röding, 1798) & - & - & $3 \pm 3.33(n=1)$ \\
\hline \multicolumn{4}{|l|}{$B U R S I D A E$} \\
\hline Bursa cruentata (G. B. Sowerby II, 1835) & $4 \pm 3.78(n=5)$ & $3 \pm 0.22(\mathrm{n}=4)$ & - \\
\hline \multicolumn{4}{|l|}{ TURBINIDAE } \\
\hline Turbo argyrostomus (Linnaeus, 1758) & $2 \pm 1.44(\mathrm{n}=2)$ & $6 \pm 1.71(n=4)$ & $1 \pm 1.44(\mathrm{n}=1)$ \\
\hline \multicolumn{4}{|l|}{ CONIDAE } \\
\hline Conus miles (Linnaeus, 1758) & $9 \pm 6.48(n=11)$ & $17 \pm 9.15(n=20)$ & $9 \pm 8.04(\mathrm{n}=11)$ \\
\hline \multicolumn{4}{|l|}{ STROMBIDAE } \\
\hline Harpago chiragra (Linnaeus, 1758) & - & $1 \pm 0.83(\mathrm{n}=1)$ & - \\
\hline \multicolumn{4}{|l|}{ CYMATIIDAE } \\
\hline Septa rubecula (Linnaeus, 1758) & $1 \pm 0.83(\mathrm{n}=1)$ & - & - \\
\hline
\end{tabular}
(Table 1).

Table 1. Diversity and density (individual per $10 \mathrm{~m}^{2}$ ) of gastropods in the Watukarung intertidal zone, Indonesia. 


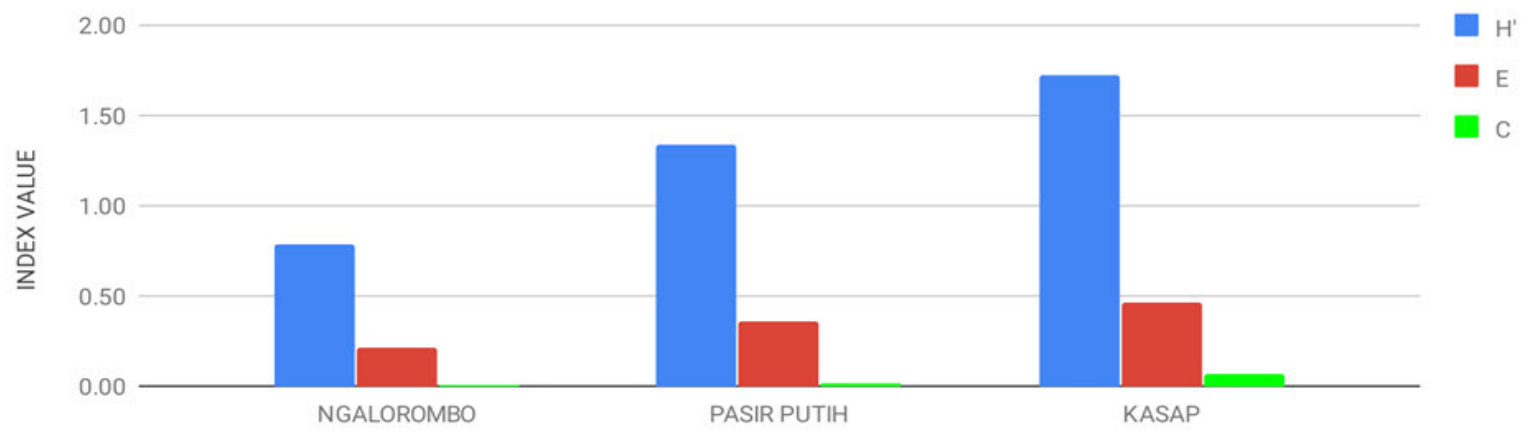

Figure 3. The Shannon-Wiener diversity index (H'), evenness index (E), and Simpson dominance index (C) in the Watukarung intertidal zone.

Gastropod diversity indices $\left(\mathrm{H}^{\prime}\right)$ at the three sites yield low and medium species diversity with the lowest diversity in Ngalorombo beach $\left(\mathrm{H}^{\prime}=0.79\right)$ and the highest in Kasap beach $\left(\mathrm{H}^{\prime}\right.$ $=1.72$ ). Gastropod evenness index (E) in these sites implies a dominant species in the ecosystem with the lowest evenness index in Ngalorombo beach $(E=0.21)$ and the highest in Kasap beach $(E=0.46)$. In contrast, the gastropod dominance index (C) shows no strong dominance species in the community $(\mathrm{C}<0.5)$. Overall, we observe higher $\mathrm{H}^{\prime}, \mathrm{E}$ and $\mathrm{C}$ values at Kasap compared to the other two sites (Figure 3).

\section{Environmental Conditions}

Data on water quality parameters (temperature, salinity, $\mathrm{pH}$, and $\mathrm{DO}$ ) and substrate analysis at Ngalorombo, Pasir Putih, and Kasap are shown in Tables 2 and 3, respectively. The water quality parameters were measured during low tide condition in the coastal waters of the beaches showing healthy environments for marine organisms. The substrate analysis shows that the three sites share a similar substratum comprising rocky structures and sand. Based on the percentage of the fraction of the substrate, the three locations are classified into sandy substrate dominated by coarse sand. TOM values at the three beaches range between 1.9 to $2.6 \%$. These low TOM values are indicative of a rocky and coarse sand substrate.

Table 2. Observed water quality parameters in Watukarung coastal waters.

\begin{tabular}{|l|c|c|c|}
\hline \multirow{2}{*}{ Water quality parameters } & \multicolumn{3}{|c|}{ Observation Sites } \\
\cline { 2 - 4 } & Ngalorombo & Pasir Putih & Kasap \\
\hline Temperature $\left({ }^{\circ} \mathrm{C}\right)$ & $24.8 \pm 0.00$ & $25.5 \pm 0.15$ & $34.2 \pm 0.57$ \\
\hline Salinity $(\%)$ & $31.0 \pm 0.33$ & $31.0 \pm 0.88$ & $8.2 \pm 0.03$ \\
\hline $\mathrm{DO}(\mathrm{mg} / \mathrm{L})$ & $8.4 \pm 0.17$ & $8.1 \pm 0.13$ & $9.1 \pm 0.05$ \\
\hline $\mathrm{pH}$ & $8.5 \pm 0.06$ & $8.0 \pm 0.05$ & \\
\hline
\end{tabular}

Table 3. Substrate fraction in the Watukarung intertidal zone

\begin{tabular}{|l|c|c|c|c|c|}
\multirow{2}{*}{$\begin{array}{c}\text { Observation } \\
\text { Site }\end{array}$} & $\begin{array}{c}\text { Very Coarse Sand } \\
(1-2 \mathrm{~mm})\end{array}$ & $\begin{array}{c}\text { Coarse Sand } \\
(500 \mu \mathrm{m}-1 \mathrm{~mm})\end{array}$ & $\begin{array}{c}\text { Medium Sand } \\
(250-500 \mu \mathrm{m})\end{array}$ & $\begin{array}{c}\text { Fine Sand } \\
(125-250 \mu \mathrm{m})\end{array}$ & $\begin{array}{c}\text { Total } \\
\text { Organic } \\
\text { Matter (\%) }\end{array}$ \\
\hline Ngalorombo & 42.1 & 45.8 & 11.8 & 0.3 & 1.90 \\
\hline Pasir Putih & 28.7 & 56.9 & 14.3 & 0.1 & 2.63 \\
\hline Kasap & 5.0 & 72.5 & 20.8 & 0.7 & 1.93 \\
\hline
\end{tabular}




\section{DISCUSSION}

The composition of gastropods in Ngalorombo, Pasir Putih, and Kasap beaches in Watukarung intertidal zone is dominated by species adapted to rock and coarse sand environments. Strong wave movements shift fine particles as suspensions and leave behind the sand (Nybakken, 1988). The numbers of the observed individual are slightly low that could be due to the limiting factor of gastropod life cycle such as the presence of strong wave movement. Strong wave movements in intertidal and tidal areas can decrease the number or size of gastropods (Krebs, 1972).

The diversity index of gastropods in the three beaches are categorized as low and medium species diversity with Kasap beach having the highest diversity as well as evenness $\left(\mathrm{H}^{\prime}=1.86\right.$, $\mathrm{E}=0.50$ ). The relatively low values of $\mathrm{H}^{\prime}$ and E possibly are due to anthropogenic disturbances from local people collecting gastropods for supplementary foods and souvenirs (Figure 4) as well as extreme environmental conditions in the intertidal zone such as dramatic changes in habitat from high to low watermarks or being exposed to air for several days at a time (Schonbeck and Norton, 1980; Hookham et al., 2014). There is no dominant species of gastropod in the Watukarung intertidal zone as suggested by the $\mathrm{C}$ value $<0.5$. The species of Cypraeidae is present in all three sites. Most Cypraeidae species are herbivorous grazers with some carnivorous and sponge eaters. They are found in the lower and middle intertidal areas including shallow water, tide pools, under stones or among seagrasses in rocky, muddy, and sandy shores, (Passamonti, 2015; Villamor and Yamamoto, 2015). We assume that Cypraeidae's density is highest in Kasap because local people very rarely visit this beach as it is more exposed to the Indian Ocean thus higher safety risks, whereas Ngalorombo and Pasir Putih beaches are more accessible by the local people.

The low TOM values may be due to low input of organic matter from the land field to the coastal waters. In addition, coarse sandy substrate quickly drains the water in the intertidal zone during low tide and cannot hold organic matter longer in the intertidal zone. Although the value of TOM is low, nutrients are not a limiting factor for organisms living in the intertidal zone. There is a direct transfer of nutrients from seawater into the intertidal zone by waves (Nybakken, 1988). This condition must be maintained by the local community, government and private sector because sustainable tourism and fisheries depend on healthy marine environments. As a tourist destination, Watukarung beaches need to be managed properly to profit the local people while reducing environmental problems.

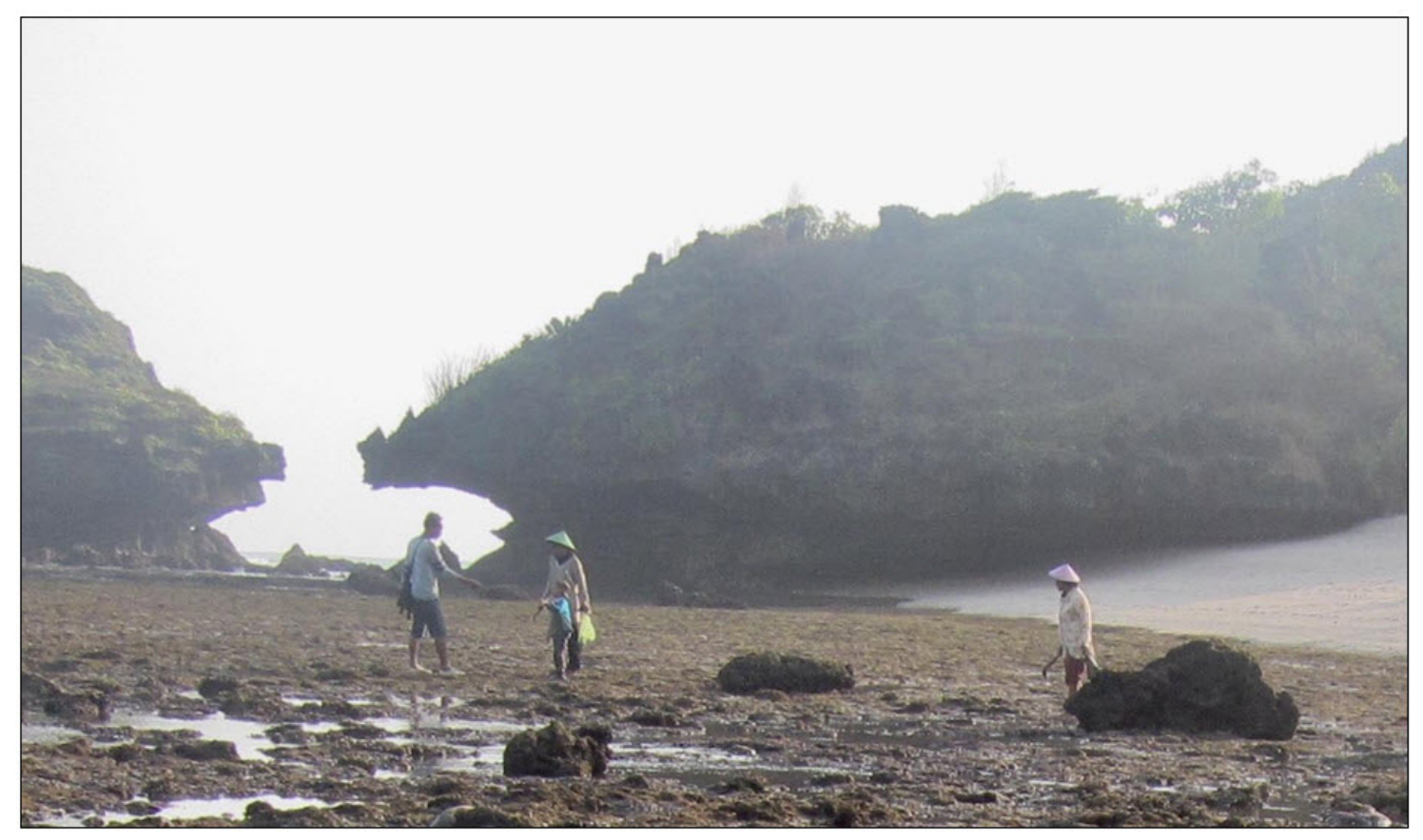

Figure 4. Local people collecting gastropods and seaweed in Pasir Putih beach. 
Government Regulation No. 60/2007 on fishery resources conservation could serve as a legal framework for environmental management in Watukarung. Marine protected areas consist of four zones, namely: (i) core zone that protects habitats for spawning and nursery, fish population, unique coastal ecosystems or traditional culture sites, and allows research and education, (ii) sustainable fisheries zone that allows environmentally friendly fisheries and aquaculture activities, as well as marine tourism, (iii) usage zone is mainly for ecotourism, and (iv) miscellaneous zone for specific purposes, such as for rehabilitation (Setyawati, 2014). Based on our study, Kasap beach can be established as a core zone considering its high diversity and density of gastropods. Moreover, the beach area is located far from the residential community; therefore, it is feasible to implement the protection of natural organisms. The local community also need to be educated to protect the coastal area of Kasap for sustainability. Ngalorombo and Pasir Putih beaches fit as a usage zone because the area has suitable waves that attract surfing activities.

\section{CONCLUSION}

Our study presents ecological and environmental conditions of gastropods in Ngalorombo, Pasir Putih, and Kasap beaches in Watukarung intertidal zone, Indonesia, to provide a baseline for identifying their potential zonation. Our survey collected 173 individuals of gastropod in the intertidal area of Watukarung that represent 8 families, 9 genera, and 13 species. Based on the results, we suggest that Kasap beach can be established as a core zone considering its high diversity and density of gastropods as well as being distant from any residential area, whereas Ngalorombo and Pasir Putih beaches are suitable as usage zones with waves for surfing tourism. It is important for the local community, government, and private sector need to work together to encourage sustainably tourism while reducing environmental impacts.

\section{ACKNOWLEDGEMENTS}

All authors contributed equally to this work. We would like to thank Mr. Slamet and Mrs. Harmini of the Watukarung village for helping us collecting the samples.

\section{REFERENCES}

Abbot, R. T. (1969). Indo - Pacific Mollusca Volume 1. Philadelphia, PA: Academy of Natural Sciences of Philadelphia.

Bloch, C. P. (2012). Why snails? How gastropods improve our understanding of ecological disturbance. Bridgewater Rev., 31(2), 8-13.

Blott, S. J., and Pye, K. (2001). GRANDISTAT: A grain size distribution and statistics package for the analysis of unconsolidated sediments. Earth Surf. Proc. Land., 26, 1237-1248. doi:10.1016/S0167-5648(08)70015-7.

Brower, J. E, and Zar, J. H. (1990). Field and Laboratory Methods for General Ecology. Dubuque, IA: WMC Brown Company Publisher.

Davis, J. P., Pitt, K. A., Connolly, R. M., and Fry, B. (2015). Community structure and dietary pathways for invertebrates on intertidal coral reef flats. Food Webs, 3, 7-16. doi:10.1016/j. fooweb.2015.04.001.

De Kock, K. N., Joubert, P. H., and Pretorius, S. J. (1989). Geographical distribution and habitat preferences of the invader freshwater snail species Lymnaea columella (Mollusca: Gastropoda) in South Africa. Onderstepoort J. Vet. Res., 56(4), 271-275.

Hookham, B., Shau-Hwai, A. T., Dayrat, B., and Hintz, W. (2014). A baseline measure of tree and gastropod biodiversity in replanted and natural mangrove stands in Malaysia: Langkawi Island and Sungai Merbok. Trop. Life Sci. Res., 25(1), 1-12.

Krebs, C. J.(1972).ECOLOGY: The Experimental Analysis of Distribution and Abundance. New York, NY: Harper and Row Publisher Inc.

Mouritsen, K. N., and Poulin, R. (2002). Parasitism, community structure and biodiversity in intertidal ecosystems. Parasitol., 124(7), 101-117. doi:10.1017/ s0031182002001476.

Nybakken, J. W. (1988). Biologi Laut. Suatu pendekatan ekologis. Translated from Marine Biology an Ecologycal Approach by Eidman M., Koesbiono, Bengen D. G., and Sukardjo S. Jakarta, ID: PT Gramedia Pustaka Utama. 
Odum, E. P. (1993). Dasar-dasar Ekologi 3rd. Translated from Fundamental of Ecology by Samingan T. Yogyakarta, ID: Gadjah Mada University Press.

Passamonti, M. (2015). The family Cypraeidae (Gastropoda Cypraeoidea) an unexpected case of neglected animals. Biodiv. J., 6(1), 449-466.

Picardal, R. M., and Dolorosa, R. G. (2014). The molluscan fauna (gastropods and bivalves) and notes on environmental conditions of two adjoining protected bays in Puerto Princesa City, Palawan, Philippines. J. Entomol. Zool. Stud., 2(5), 72-90.

Poutiers, J. M. (1998). Gastropods. In K. E. Carpenter and V. H. Niem. (Eds.), FAO Species Identification Guide for Fishery Purposes. The living marine resources of the Western Central Pacific. Volume 1. Seaweeds, corals, bivalves, and gastropods. Rome: FAO. (pp. 363-648).

Reid, D. G. (1985). Habitat and zonation patterns of Littoraria species (Gastropoda: Littorinidae) in Indo-Pacific mangrove forests. Biol. J. Linnean Soc., 26(1), 39-68. doi:10.1111/j.1095-8312.1985.tb01551.x.

Schonbeck, M. W., and Norton, T.A. (1980). Hostinduced changes in the cell surface n-linked glycoproteins, from Aspergillus fumigatus.
Search for specific targets with potential for clinical therapy and/or diagnosis. J. Exp. Mar. Biol. Ecol., 43, 131-150. doi:10.1016/00220981(80)90021-0.

Setyawati. (2014). Managing marine protected areas in Indonesia. J. Mar. Biol. Association India, 56(1), 13-18. doi:10.6024/ jmbai.2014.56.1.01750s-02.

Silulu, P. F., Boneka, F. B., and Mamangkey, G. F. (2013). Biodiversitas kerang oyster (Mollusca, Bivalvia) di daerah intertidal Halmahera Barat, Maluku Utara. J. Ilmiah Platax, I-2, 67-73. doi:10.35800/jip.1.2.2013.124.

Smale, D. A., Barnes, D. K. A., Barnes, R. S. K., Smith, D. J., and Suggett, D. J. (2012). Spatial variability in the structure of intertidal crab and gastropod assemblages within the Seychelles Archipelago (Indian Ocean). J. Sea Res., 69, 8-15. doi:10.1016/j.seares.2012.01.002.

Villamor, S., and Yamamoto, T. (2015). Population characteristics of Monetaria annulus (Linnaeus, 1758) (Gastropoda: Cypraeidae). Aquacult. Sci., 63(3), 273-282. doi:10.11233/aquaculturesci.63.273.

Yulianda, F., Yusuf, M. S., and Prayogo, W. (2013). Zonasi dan kepadatan komunitas intertidal di daerah pasang surut, pesisir Batuhijau, Sumbawa. JITKT, 5(2), 409-416. doi:10.28930/jitkt.v5i2.7569. 